\title{
The summer diet of the magellanic horned owl (Bubo magellanicus, Gmelin, 1788) at the easternmost projection of continental Chile, Punta Dungeness
}

\author{
Dieta estival del tucúquere (Bubo magellanicus, Gmelin, 1788) \\ en el extremo oriental de Chile continental, Punta Dungeness
}

David R. Martínez ${ }^{1}$

For most of southern South America, particularly Chile and Argentina, the food habits of the Magellanic Horned Owl (Bubo magellanicus) are well known. In continental Chile, several researchers such as Jaksić et al. (1978), Jaksić \& Marti (1984), Jaksić et al. (1986), and Iriarte et al. (1990) have reported the owl's diet for locations in subpolar forests and other environments, but as far as I know, no food habits data are available for their southernmost continental distributional range in a typical Patagonian steppe environment. Only in Argentina, and on a latitudinal basis, Trejo \& Grigera (1998) Formoso et al. (2012), and Massoia et al. (1994) have reported the owl's diet for individuals inhabiting Patagonian steppe and grassland.

Here, I report for the first time (at least for Chile) the summer diet of Magellanic Horned Owls in a southernmost continental Patagonian steppe environment (sensu Gajardo, 1994). Also, I report the contribution of austral cavies (Microcavia australis) to its diet, a small mammal species otherwise considered extinct in Chile.

The study site is located in Punta Dungeness (52 20'57.55”S, 68 $\left.26^{\prime} 08.61^{\prime \prime} \mathrm{W}\right)$, which is a cuspate foreland formed by accretion and progradation of sand and shingle, located at the eastern entrance of the Magellan strait on its northern coast, and represents the southernmost end of the mainland of South America. The landform is opposite to Espíritu Santo cape in adjacent Tierra del Fuego island. At the southern tip of Punta Dungeness, a lighthouse operated by the Chilean Navy signals the easternmost projection of continental Chile. Almost $50 \%$ of its surface is occupied by vegetation corresponding to the Lepidophyllum cuppressiforme - Festuca gracillima association or "Mata Negra" and "Coirón Dulce". The remaining fraction is covered by sand and cobbles. The roosting site was in the occidental border of the vegetated fringe that covers partially the accretion tip. It is an almost flat landscape on which the most notorious terrain forms were low altitude (10 m.a.s.l.) dunes with slopes covered mostly by small size shrubs such as Berberis buxifolia (calafate) and Lepidophyllum cupressiforme (mata negra), whereas the bottom was covered by patches of vegetation and sand. The owl pair perched on prostrated branches of old calafate or mata negra bushes. Surroundings the roosting site were patches of calafate and mata negra, and interspersed smaller shrubs such as Adesmia boronioides, Senecio patagonicus and some coirón (Festuca gracillima) clumps.

On January 2017 (austral summer) and at the site described above, I collected 43 Magellanic Horned Owl's pellets scattered under the shrubs used by the owl pair as perches. From the whole sample I measured and weighed 29 intact pellets.

I identified and quantified most vertebrates in the pellets on the basis of skulls (Pearson, 1995) or dentary pairs (whichever gave the highest

\footnotetext{
1 Laboratorio Comunidades y Restauración Ecológica, Departamento Ciencias Biológicas y Biodiversidad, Universidad de Los Lagos, Osorno, Chile.

$\measuredangle$ dmartin@ulagos.cl
} 
count). For other remains, such as feathers, I used reference collections and quantified these prey assuming the smallest possible number of individuals (e.g. feathers of a given species were deemed as representing only one individual). For insect identification, I followed Peña (1986) and Elgueta et al. (2013) and quantified these prey by counting head capsules and mandibles. I identified prey items to the highest resolution taxonomic category. Prey mass estimates were taken from the literature (Pearson, 1983; Jaksić et al. 1986; Lozada et al. 1996; Pardiñas \& Calliari, 2001; Tognelli et al. 2001; Teta et al. 2009). I estimated the biomass contribution of each prey type to the owls' diet by multiplying the number of individuals in the pellets by the mean body mass of that item. I assumed that masses of unidentified prey were similar to the average mass of the most closely related identified taxa. To characterize the diet, I used as food descriptors the geometric mean mass of prey (GMMP; Marti, 1987), the food niche breadth (FNB) using Levin's index (Levins, 1968) and Simpson's reciprocal index (Simpson, 1949) as well its standardized version (FNBs) according to Colwell \& Futuyma (1971).

The 29 whole pellets averaged $55.5 \pm 2.1$ $\mathrm{mm} \times 25.5 \pm 0.4 \mathrm{~mm}$ and had a mean dry mass of $6.8 \pm 0.51 \mathrm{~g}(\mathbb{\Delta} \pm \mathrm{SE})$. There are no published reports for these data nearby, as Anahí Formoso (pers. comm., 2015) reported that no whole pellets were available at Cabo Vírgenes lighthouse site (Formoso et al. 2012) located at roughly $2500 \mathrm{~m}$ $\mathrm{NE}$ of the collecting site, thus comparisons with northern data were not possible (e.g. Yánez et al. 1978, Jaksic et al. 1986, Nabte et al. 2006).

The 43 pellets analyzed yielded 118 prey items (Table 1) of which small mammals were the most frequent prey, both by number an biomass.

By numbers, both the southern pericote (Loxodontomys micropus) and the yellow-nosed mouse (Abrothrix xanthorhinus) were the most common vertebrate prey in the diet, although the biomass contribution of the former was the highest of all prey consumed, thus being the staple food for Magellanic Horned owls, at least for summertime. The yellow-nosed mouse biomass's contribution was well surpassed by southern cavies (Microcavia australis), bunny rats (Reithrodon auritus), and leverets (Lepus europaeus). The bunny rat, also commonly named rata conejo or coney rat, although by numbers were third, in terms of biomass contribution were second as compared to yellownosed mice. Regarding southern cavies and the introduced european or brown hares, despite being numerically scarce, their biomass contribution was important, following those contributed by southern pericotes. Thus, southern pericotes, southern cavies, bunny rats and leverets accounted for ca. $84.0 \%$ of all biomass consumed during summer.

Birds of the family Furnariidae made minor contributions in biomass, and at least four specimens were most probably Short-billed Miners (Geositta antarctica).

The contribution of lizards (Tropiduridae) to total biomass consumed was negligible, and the tail remain observed was assigned to Liolaemus magellanicus, the only lizard species more commonly reported for the area (Venegas \& Sielfeld, 1998).

Although insects were numerically abundant, their biomass contribution was unimportant (less than $0.5 \%$ ). Individuals of Geotrupidae (earth-boring dung beetles) and Carabidae were numerically important, followed by some specimens of Promecheilidae (formerly Perimylopidae). The last family of these darkling beetles is related to Australia and New Zealand fauna (Elgueta et al. 2013). The geometric mean mass of prey items was $43.8 \mathrm{~g}$, whereas the trophic niche breadth was $\mathrm{FNB}=6.544$ and its standardized version was $\mathrm{FNBs}=0.554$. This last value is at odds with the latitudinal trend proposed by Jaksić et al. (1986), in terms that diversity of prey in the owl's overall diet decreased steadily towards southern latitudes. Recently, Muñoz-Pedreros et al. (2017) re-analyzed this purportedly latitudinal variations in diet of this owl species including a greater number of localities $(\mathrm{N}=$ 5) but no clear latitudinal pattern was detected. Most likely, results from all studies above may reflect the local availability and/or spectrum of prey at the time when diets were evaluated. However, in the case of Bubo magellanicus, results may also be an artifact of the low number of sampled localities (Figueroa et al. 2017). Alternatively, the diet here reported for Magellanic Horned owls comprises a prey profile, in terms of species composition and abundance, that is typical of Patagonian steppe, environment not represented on all studies above cited. 
Table 1. Summer diet of the Magellanic Horned Owl (Bubo magellanicus) at Punta Dungeness, easternmost projection of continental Chile.

\begin{tabular}{|c|c|c|c|}
\hline & Mass & & Biomass \\
\hline PREY & (g) & $\mathrm{N}$ & $\%$ \\
\hline \multicolumn{4}{|l|}{ Mammals } \\
\hline Abrothrix xanthorhinus & 17.5 & 26 & 9.2 \\
\hline Loxodontomys micropus & 63 & 26 & 33.0 \\
\hline Reithrodon auritus & 80 & 12 & 19.3 \\
\hline Microcavia australis & 263 & 4 & 21.2 \\
\hline Lepus europaeus (leverets) & 127 & 4 & 10.2 \\
\hline Unidentified rodents & 53.5 & 3 & 3.2 \\
\hline Subtotal mammals & & 75 & 96.1 \\
\hline \multicolumn{4}{|l|}{ Birds } \\
\hline Unidentified passerines & 27 & 6 & 3.2 \\
\hline Subtotal birds & & 6 & 3.2 \\
\hline \multicolumn{4}{|l|}{ Tropiduridae (lizards) } \\
\hline Liolaemus magellanicus & 15 & 1 & 0.3 \\
\hline Subtotal Tropiduridae & & 1 & 0.3 \\
\hline \multicolumn{4}{|l|}{ Insects (Coleoptera) } \\
\hline Carabidae & 0.5 & 15 & \\
\hline Geotrupidae & 0.5 & 18 & \\
\hline Promecheilidae & 0.5 & 3 & \\
\hline Subtotal insects & & 36 & 0.4 \\
\hline Total prey items & & 118 & \\
\hline Total biomass (g) & & 4968.5 & \\
\hline Total pellets & & 43 & \\
\hline FNB & & 6.544 & \\
\hline FNBs & & 0.554 & \\
\hline GMMP & & 43.81 & \\
\hline
\end{tabular}

Finally, it now appears that a thriving population of Austral cavies (Microcavia australis) inhabits the northeastern continental coastal fringe of Magellan strait, proving that the species has successfully re-colonized the area, where it was previously presumed extinct (Muñoz-Pedreros \& Gil, 2009).

The results also re-assures the fact that owl pellets analysis is a fast, non-invasive and cost-efficient tool, better than traps at assessing small mammals community composition (Rau et al. 2005, Heisler et al. 2016) for almost every terrestrial environment.

\section{ACKNOWLEDGEMENTS}

I thank Dr. Carlos Ríos C. for his friendship and for considering my participation in GEAUMAG environmental activities. Also I thank ENAP-Magallanes crew at Campamento Posesión for a great stay. This work was funded by ENAPMagallanes under contract "Fauna Dungeness". 


\section{LITERATURE CITED}

Colwell, R. K., \& Futuyma D. J. (1971). On the measurement of niche breadth and overlap. Ecology, 52, 567-576.

Elgueta M., Flores G. E., \& Roig-Juñent S. (2013). Algunos coleópteros (Coleoptera: Carabidae, Promecheilidae) de Islas Diego Ramírez (56³2'S; 6843W), región de Magallanes. Anales Instituto Patagonia, 41(1), 141-146.

Figueroa R. A., Alvarado S., Corales E. S., González-Acuña D., Schlatter R., \& Martinez D. R. (2017). The Owls of Chile. In P. Enríquez (Ed.), Neotropical Owls. Diversity and Conservation (pp. 159-290). Springer International Publishing AG.

Formoso, A., Teta, P., \& Cheli G. (2012). Food Habits of the Magellanic Horned Owl (Bubo virginianus magellanicus) at southernmost Patagonia, Argentina. Journal of Raptor Research, 46(4), 401-406.

Gajardo R. (1994). La vegetación natural de Chile. Clasificación y distribución geográfica. Santiago de Chile: Editorial Universitaria.

Heisler, L. M., Somers C. M., \& Poulin R. G. (2016). Owl pellets: a more effective alternative to conventional trapping for broad-scale studies of small mammals communities. Methods in Ecology and Evolution, 7, 96-103.

Iriarte J. A., Franklin W. L., \& Johnson W. E. (1990). Diet of sympatric raptors in southern Chile. Journal of Raptor Research, 24(3), 41-46.

Jaksić, F. M., Yáñez J. L., \& Rau J. R. (1978). Oferta de presas y predación por Bubo virginianus (Strigidae) en el Parque Nacional Torres del Paine. Anales Instituto Patagonia, 9, 199202.

Jaksić, F.M., Yáñez J. L. \& Rau J. R.(1986). Prey and trophic ecology of Great Horned Owls in western South America: an indication of latitudinal trends. Journal of Raptor Research, 20: 113-116.

Jaksić, F. M., \& Marti C.D. (1984). Comparative food habits of Bubo owls in mediterraneantype ecosystems. The Condor, 86, 288296.

Levins R. (1968). Evolution in changing environments. Princeton, NJ: Princeton University Press.

Lozada, J. M., Monjeau A., Heinemann K. M., Guthmann N., \& Birney E. C. (1996). Abrothrix xanthorhinus. Mammalian Species, 540, 1-6.

Marti CD. (1987). Raptor food habits studies. In B. A. G. Pendleton, B. A. Millsap, K. W. Kline, D. M. Bird (Eds.), Raptor Management Techniques Manual (pp. 6780). Washington, D.C.: National Wildlife Federation.

Massoia, E., Chévez J. C., \& Heinonen D. S. (1994). Depredación de pequeños mamíferos por Bubo virginianus en el Lago Cardiel, Departamento Lago Buenos Aires, provincia de Santa Cruz. Boletín Científico, Asociación para la Protección de la Naturaleza, 26, 17-21.

Muñoz-Pedreros A., \& Gil C. (2009). Orden Rodentia. En A. Muñoz-Pedreros, A. \& J.L. Yáñez (Eds.), Mamíferos de Chile, (pp. 93-57), Segunda Edición. Valdivia: CEA Ediciones.

Muñoz-Pedreros A., Yáñez J., Gil C., Norambuena H. V., \& Carmona E. R. (2017). Spatial differences in the diet of the Magellanic horned owl Bubo magellanicus (Gmelin, 1788) in central Chile. New Zealand Journal of Zoology, 44(1), 25-38.

Nabte, M., Saba S., \& Pardiñas U. (2006). Dieta del Búho Magallánico (Bubo magellanicus) en el desierto del monte y la Patagonia Argentina. Ornitología Neotropical, 17, 27-38.

Pardiñas, U. F. J., \& Galliari C. A. (2001). Reithrodon auritus. Mammalian Species $664,1-8$.

Pearson, O. (1983). Characteristics of a mammalian fauna from forests in Patagonia, southern Argentina. Journal of Mammalogy, 64, 476-492.

Pearson, O. (1995). Annotated keys for identifying small mammals living in or near NahuelHuapi National Park or Lanin National Park, Southern Argentina. Mastozoología Neotropical, 2, 99-148.

Peña, L. E. (1986). Introducción a los insectos de Chile. Santiago de Chile: Editorial 
Universitaria.

Rau J. R., Muñoz-Pedreros A., \& Martínez D. R. (2005). Diversidad trófica de aves rapaces y mamíferos carnívoros en la Cordillera de la Costa. En C. Smith, J. J. Armesto \& C. Valdovinos (Eds.), Historia, biodiversidad y ecología de los bosques costeros de Chile, (pp. 518-519). Santiago de Chile: Editorial Universitaria, Serie Bosque Nativo.

Simpson E. H. (1949). Measurement of diversity. Nature, 163, 688.

Teta P., Pardiñas U. J., Udrizar Sauthier D. E., \& D'Elia G. (2009). Loxodontomys micropus (Rodentia: Cricetidae). Mammalian Species, 837, 1-11.
Tognelli M. F., Campos C. M., \& Ojeda R. A. (2001). Microcavia australis. Mammalian Species, 648, 1-4.

Trejo. A., \& Grigera, D. (1998). Food Habits of the great horned owl (Bubo virginianus) in a Patagonian steppe in Argentina. Journal of Raptor Research, 32(4), 306-311.

Venegas C., \& Sielfeld W. (1998). Catálogo de los vertebrados de la región de Magallanes y Antártica chilena. Punta Arenas: Ediciones Universidad de Magallanes.

Yáñez, J., Rau J., \& Jaksić F. (1978). Estudio comparativo de la alimentación de Bubo virginianus (Strigidae) en dos regiones de Chile. Anales del Museo de Historia Natural de Valparaíso, 11, 97-104. 